\title{
The Pacific Submarine Cable and Its Impact on Japan in the 19th Century
}

\section{Tomoko Hasegawa}

Global Exchange Organisation for Research and Education, Gakushuin University, Toshima, Japan

Email: 20150225@gakushuin.ac.jp

How to cite this paper: Hasegawa, T. (2016) The Pacific Submarine Cable and Its Impact on Japan in the 19th Century. Open Access Library Journal, 3: e3001. http://dx.doi.org/10.4236/oalib.1103001

Received: August 24, 2016

Accepted: September 27, 2016

Published: September 30, 2016

Copyright (C) 2016 by author and Open Access Library Inc.

This work is licensed under the Creative Commons Attribution International License (CC BY 4.0).

http://creativecommons.org/licenses/by/4.0/

(c) (i) Open Access

\begin{abstract}
The submarine cable served as one of the most important tools of the western powers in their quest for empire-building and commercial profits in the 19th century. Thus the construction of a submarine cable across the Pacific Ocean became a priority for the western powers, especially the United States and the United Kingdom, in pursuit of their commercial and political interests into the Asian market. The construction of the Pacific Submarine Cable (PSC) equally impacted the Asian side, particularly Japan. This article examines the economic and political impact of the construction of the PSC on Japan, which was transitioning from its centuries-old Shōgunate rule into the Meiji or modern era. It argues that while the new technology was able to help modernize the Japanese military as well as develop its national economy through the active participation of the newly-emerged business community, the government was however, unable to formulate its own independent telecommunications policy due to the control of the technology by foreign powers and corporations, especially the Great Northern Telegraph Company. It is emphasized here that the information used for this article is largely based on the official documents from the Japanese government archives.
\end{abstract}

\section{Subject Areas}

Economics, Electric Engineering

\section{Keywords}

Pacific Submarine Cable, Japan's Modernization, Business Community

\section{Introduction}

The construction of the Pacific Submarine Cable (PSC) in the 19th century, designed to connect the North American and the Asian continents, was regarded by both the US 
and the UK as one of the essential tools required to penetrate the Asian market, especially the Chinese market. The two powers therefore, considered Japan's location in the construction process as strategically important to their plan thus drawing Japan into the construction of the PSC politics.

However, existing records pertaining to Japan's telecommunications policies during this period, have persuaded majority of current researchers on the topic to focus more on Japan's relationship with the Danish company, the Great Northern Telegraph Company (GNTC, precisely it was "The Great Northern Extension China and Japan Telegraph Company", one of the group companies of the Great Northern Telegraph Company), which, for several years, held exclusive rights to the construction of Japan's international submarine cable requirements in East Asia, than on research pertaining to the PSC itself. Japan's telecommunications technology since the Meiji era (1868) has been argued to have contributed to not only the state-building and domestic economic development but also questing empire-building [1]. In particular, several authors, including Yang (2010), have discussed Japan's international submarine cable policy during the Meiji period from the perspective of its overseas expansion in East Asia, regarding the empire-building argument.

Similarly, Ariyama's recent study, Jōhō Haken to Teikoku Nihon Vol. 1, 2 (Tokyo: Yoshikawa Kōbunkan, 2013), which discusses the shaping of Japan's international telecommunications and news distribution policy since the latter part of the 19th century, also focuses on the process of completing the laying of the PSC in 1906, as a result of the negotiations which occurred between the Japanese government and the US company, the Commercial Pacific Cable Company (CPCC) which finally completed the PSC. According to Ariyama, even though the PSC plan had existed since the beginning of the Meiji era, it was not easily realized because Japan did not have enough funding and the technological expertise to lead the project. Thus, Japan had to depend on the US and other countries for laying the PSC, implying that Japan did not have the initiative to promote the plan [2]. While Ariyama's study focuses on the negotiations between the Japanese government and the CPCC since 1902 when the latter decided to lay the submarine cable between North America and Manila, still his work fails to discuss how the PSC plan had been promoted earlier within Japan.

This article discusses the political and economic impact on Japan and its new telecommunication policy as a result of the introduction of the PSC into the country especially following the end of the Sino-Japanese War (1894). It argues that Japan's support for the construction of the PSC was motivated mainly by two incentives: economic expansion and the desire to break away from its dependency on GNTC, rather than the sole empire-building ambition argued by other authors on the topic. The decision to break its dependency on the GNTC for the cable technology allowed both the UK and US companies to make several attempts to gain approval from the Japanese government to lay the PSC. Due to these repeated requests from foreign countries as well as Japan's domestic interest in the modernization of its military and social infrastructure, the demand for construction of the PSC increased in the country, not only from the Japanese 
government but also from the country's newly-emerging business community. Both the government and the business community sought to increase the volume of Japan's international trade as well as the growth of the national economy thus they considered the PSC their opportunity to escape from the monopolistic clutches of the GNTC, in order to achieve this goal. The business community, therefore, became an active participant in the government's formulation of the country's international submarine cable policy, adding the economic importance of the PSC to the entire policy after the SinoJapanese War.

\section{Japan's Support and Promotion of the PSC in the Post-Sino-Japanese War (1894)}

As the world submarine cable network expanded in the 1860's, western powers, especially the UK and the US, considered Japan a critical site for the construction of the telegraphic network in Asia as crucial gateway to the Asian continent and its vast markets. During the 1870s and 1880s, the Japanese government received several applications from US private companies, individuals and government officials seeking the right to construct the PSC. However, existing records indicate that none of the many requests submitted and approved ever materialized in the construction of the PSC, due to several reasons, including the inability of the private companies to secure adequate funding for the project, the internal politics that prevailed in the US, combined with the lack of a coherent US policy on the submarine cable.

At the end of the Sino-Japanese War (1894), Japan was awarded 300 million Japanese Yen in reparations by the Chinese government. Considering the size of the Japanese government's annual budget which was about 80 million Japanese Yen, the reparations amount was huge for the government [3]. Thus the Japanese government set a new policy after the war, with two main goals in mind: military expansion and infrastructure development-such as the construction of railways and the promotion of the steel industry [3]. With this momentum of improving infrastructure as the backdrop, the Japanese economy began to expand after the war. In addition, during the post-war years and before the Russo-Japanese War (1904), there was a big surge of "Gross Amount of Trade" and the "Number of Overseas Telegrams" (see Figure 1).

During this period, the campaign for the PSC in Japan increased mostly due to its economic benefits. The campaign was led by some government officials and the business community. In this article, "business community" is defined as a community whose influence is not limited to domestic business and commerce such as industries but also in business dealings with external actor, including foreign governments. However, considering the fact that the Japanese economy was still in its formative stages, the business community was linked with the government more than it is today.

The first big campaign in support of the PSC was launched by the Tokyo Economic Association (TEA) and spearheaded by Yoshirō Sakatani, a leading member of the TEA as well as the government official for the Ministry of Treasury. He became the treasury minister after the Russo-Japanese War (1904). The TEA had a strong connection with 


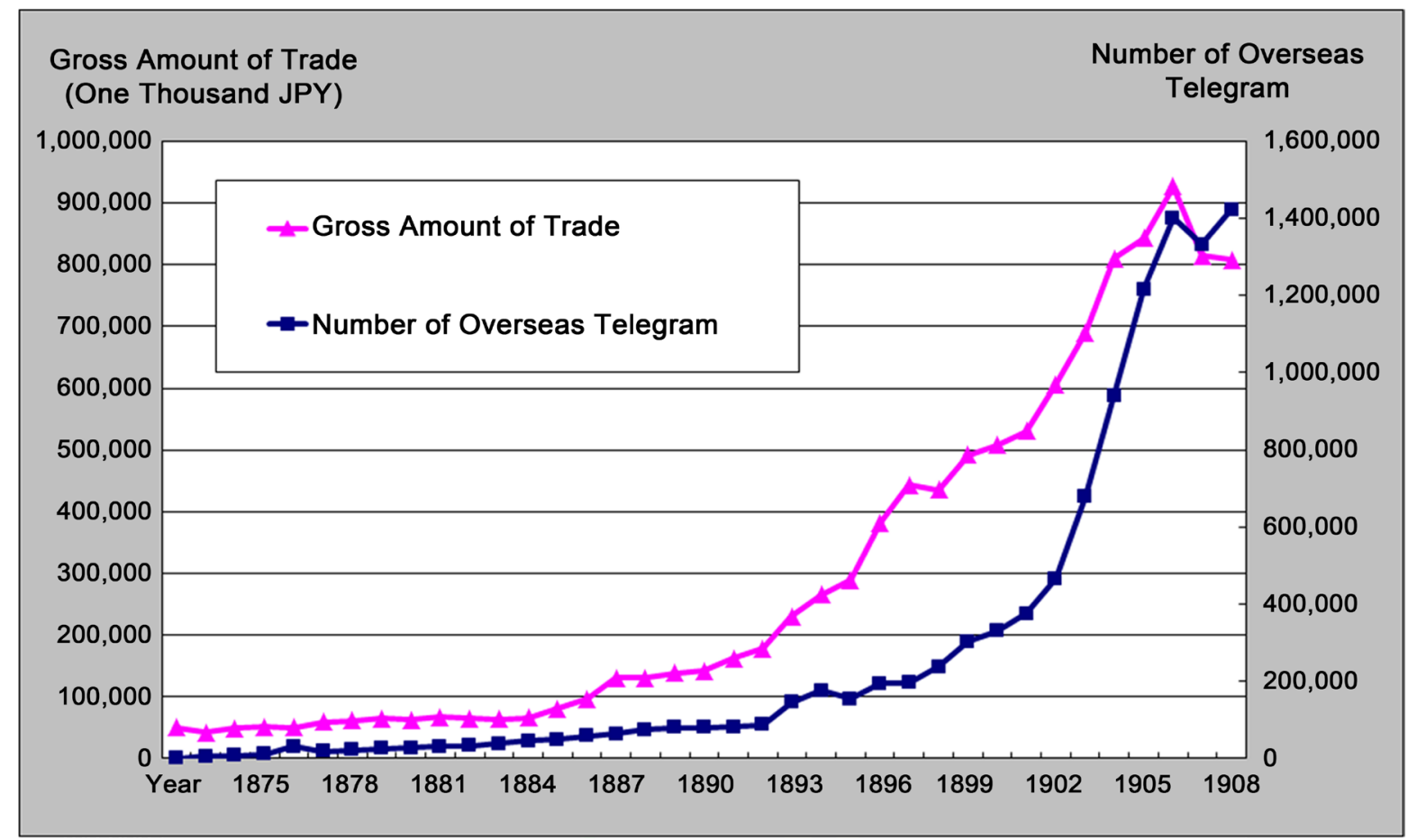

Figure 1. Gross amount trade and number of overseas telegram in Meiji era (created by author based on Nippon Denshin Denwa Kōsha (1959), Ed., Denshin Denwa Jigyōshi (History of Telephone and Telegram Business) 6th Volume, Denki Tsōshin Kyōkai, Tokyo, 768-770.

the government because some of its members were government officials. The TEA set up several economic and commercial committees charged with the task of investigating the economic and business concerns of the country. The committees submitted their final reports on these issues which were later made public.

In 1896, Sakatani proposed the constitution of an investigative committee for the PSC [4]. At the TEA's regular meeting in May 1896, he outlined and discussed the necessity and urgency of the construction of the PSC in response to the expanding economy. The TEA completed its final report on this issue indicating in the report to the government that the submarine cable could be laid by private companies, if it was difficult for the government to do so [5]. The TEA argued that laying a submarine cable between two countries was difficult to be agreed upon because both countries fought hard to exclude the element of foreign influence on their territories as much as possible. To this end, it was concluded that a contract with a foreign private company could be realized more easily than with a foreign government. This suggestion meant that Sakatani embraced the idea of private companies undertaking the construction of the PSC, even though he was a government official.

According to a Ministry of Communications report titled "The urgent necessity of laying a submarine cable between Japan and the US" [6], the Ministry drew public attention to the importance of the TEA's campaign. The report, though undated, yet seems to have been written after the Sino-Japanese War due to the expression of "after the war (Senshōgo)" contained in it. More importantly, Sakatani's speech was recorded 
by the Ministry, which believed that it was important to the Japanese people, as revealed by the report. The existence of this report indicates that the Ministry not only followed the campaign launched by the TEA and Sakatani but also realized its importance to the nation.

Additionally, within the Ministry of Communications, there existed a movement, led by Kenjirō Den, Head of the Telegraph Department (Denshinkyoku), which sought to expand the international telegraphic network. During the Sino-Japanese War, Den was in charge of intelligence gathering on the enemy. However, due to the limited network available it was not only difficult to gather the necessary information needed but it also took longer to deliver and receive messages between Japan and the UK during wartime while it took about 24 hours during peacetime. The slowness of the situation therefore frustrated both the Japanese and the UK officials which forced them to seek immediate solution to the problem.

In December 1896, Den visited the General Post Office in London after participating in the International Telegraph Convention in Budapest [7]. At the convention, he met John Cameron Lamb, the UK third secretary of the General Post Office. Den told Lamb that he had become keenly aware of the importance of improving the submarine cable network between Japan and the UK thus he proposed to Lamb for the UK to lay a submarine cable between Taiwan and Hong Kong which, according to Den, would improve the efficiency of cable communications in the region. Lamb responded positively to this proposal as he understood its importance to his country as well.

Den's plan was based on the consideration that the exclusive privilege given to the GNTC would expire in 1902 and Japan could freely lay submarine cables to connect the Asian continent and its small islands after the expiration date. Upon his return to Japan, his plan was proposed to the Minister of Foreign Affairs by the Minister of Communications [8]. However, it turned out that the treaty with GNTC would be extended for another 10 years hence this plan was never realized [9]. Although Den's idea could not be implemented, it should be noted that the Ministry of Communications tried to expand the international telegraphic network due to its discontent with the situation that prevailed.

The Ministry of Communications was not the only government institution which tried to expand the international communications network but also the Ministry of Agriculture and Commerce. In October 1896, the first meeting of an advisory council on agriculture and commerce (Nōshōkō Kōtōkaigi) was held to discuss how to improve the country's foreign trade. This advisory council included both government officials and private business persons. The council introduced a resolution which proposed that the number of consular offices should be increased to correspond to the trade volume to allow the business community to receive market information more rapidly [10].

One of the leading government officials on the council was Kentarō Kaneko, who became the vice agriculture and commerce minister after the war, and he insisted on the importance of improving the efficiency of the international communication network based on its economic benefits. He proposed to the Prime Minister, Hirobumi Itō, 
that it was urgent to expand foreign trade for the Japanese economy [11]. Kaneko envisaged closer economic relations with the US because he expected the US to become a superpower in the near future. In 1899, after he returned from a short trip to the US, he appealed for the construction of the PSC. He explained that the PSC would enable Japan to not only expand the trade volume with the US but also to escape from the clutches of GNTC and establish its own information autonomy [12].

Against the backdrop of an expanding economy and infrastructure, following the Sino-Japanese War, TEA, a member of the powerful business community of the country, strongly insisted on the importance and necessity of laying the PSC. In addition to the business community, some government agencies and leading political figures who realized the significance of the economic impact of the PSC aggressively began to appeal for the completion. These movements gained momentum within Japan after SinoJapanese War.

\section{Growing Momentum for the PSC and Its Completion}

Although both the Japanese government and the business community came to realize the importance of the PSC in assisting with their communications network at the domestic and international levels, following the Sino-Japanese War, their PSC plan was not easily accomplished as it was dependent upon the funding to be secured by the US companies.

In October 1899, the chairman of the Yokohama Chamber of Commerce (YCC), Kahei Ōtani, traveled to Philadelphia, in the US, to attend the international commercial conference as a delegate. Yokohama was the center of Japan's foreign trade from the beginning of the Meiji era hence the YCC had strong influence over the entire business community at that time. Ōtani had become successful in the Japanese tea business, which was one of the main exports to the US market since the beginning of the Meiji era, and was thus a famous person in the Japanese business community.

Before leaving Japan, Ōtani consulted with Tokunori Asada, the governor of Kanagawa prefecture, on what agenda he should present at the conference [13]. Asada suggested that he should appeal for the necessity of the PSC. He also encouraged him to speak with Akimasa Yoshikawa, the communications minister about his suggestion. Ōtani met with Yoshikawa and he also endorsed Asada's idea. Yoshikawa agreed with Asada arguing that since it had been difficult for the government to implement the PSC plan on its own, the government therefore, counted on the power of the business community to assist the country to realize the PSC plan. Yoshikawa provided the necessary information about the PSC to Ōtani after which meeting he also visited the Ministry of Foreign Affairs where he was provided with additional materials on the PSC.

At the conference, he made a speech about two subjects: the tariff for imported Japanese tea from Japan to the US, and the PSC [14]. He appealed to the conference members about the urgency of the PSC to assist in the expansion of the trade volume between Japan and the US. After the conference, he met with the president of the United 
States, William McKinley and traveled in the US to discuss business matters with his US counterparts throughout the country [15].

Following the US occupation of the Philippine Islands, McKinley, in his message to Congress in February of that year, urged lawmakers about the urgency and importance of the construction of the PSC. He told Congress: "the necessity for a speedy cable communications between the United States and all these Pacific Islands has become imperative" [16]. Again, in his State of the Union Address in December of that year, he reiterated his earlier message about the urgency and importance of the PSC. He told Congress and the nation that the "Japanese Government has shown a lively interest in the proposition of the Pacific Cable Company to add to its projected submarine cable lines to Hawaii, Guam, and the Philippines a branch connection with the coast of Japan" [17]. It could be deduced from his statement that Ōtani's speech at the conference and also his visit with McKinley had some influence in this decision.

Thus the actions of the Japanese business community, being the result of the many approaches made by foreign countries, including the US, equally impacted US domestic trade policy. More importantly, Ötani's promotion of the PSC at the conference was actively supported by the Ministry of Foreign Affairs and the Ministry of Communications.

In Japan, the promotion of the PSC plan increased and finally, a proposition for constructing the PSC was submitted to the national diet, which was called "the Imperial Diet" at the time. In 1900, three Assembly Members submitted a proposal to the Japanese Parliament concerning the necessity of the PSC [18]. Among them was Kakugorō Inoue, a well-known businessman who had helped to establish the railway and steel industries, hence had a strong connection with the business community.

The proposal outlined three major concerns. First, it highlighted the benefits of the PSC in helping to decrease the telegram rates for the economy. It also argued that Japan would have to use one of two routes: the one across Russia, or the other across India and Europe to reach North America. The Members contended that the cost involved in the use of the two routes would be too exorbitant for the country to bear, thus adversely impacting Japanese trade business. Second, they referred to Japan's trade surplus with the US. They explained that although China and the UK were Japan's biggest trading partners, the latter (Japan) had trade deficits with these two countries. On the contrary, Japan had trade surplus with the US, therefore, they urged the Japanese government to consider promoting its trade with the U.S. instead. The PSC, they argued, would contribute to the increase of the volume of trade with the US and expand the size of the Japanese economy overall.

Lastly, they referred to two events from the US side-the State of the Union Address made by McKinley, and the approach by the Pacific Cable Company of New York in 1898. According to them, these two events indicated the readiness of both the US government and the private company, regarding the construction of the PSC. Thus they appealed to the Japanese government to respond quickly to the interest shown by the US, in order not to lose the opportunity presented. These three major reasons thus 
served to underline the proposal submitted by the Assembly Members concerning the importance and the urgency involved in the construction of the PSC.

The deepening rivalry with Russia in East Asia at the end of the 19th century also made Japan accelerate its negotiations concerning the construction of the PSC plan. Russia pursued its foreign expansionist policy of "Pushing Southward" for acquiring an ice-free port and accelerated its influence over the weakening China, while Japan wanted to strengthen its control over the Korean Peninsula following its victory over China. Thus, the military presence of both powers in the region clashed eventually, in the Russo-Japanese War of 1904, in which Japan again, emerged the victor. However, as the conflict between Japan and Russia intensified, the Japanese Army demanded the government should seek an alternative way of completing the PSC construction that would enable it to escape from its dependency on the GNTC and to enhance its military advantage in the region [19]. This request also helped to increase the military importance of the PSC technology. Thus, following the Sino-Japanese war, domestic interest in the PSC plan gradually gained momentum in Japan due to the country's business and economic expansion and military interests. It became evident therefore, that the only way to escape from the clutches of the GNTC control was for Japan to pursue the construction of a submarine cable which connected other continents besides Asia. This therefore, compelled the government to focus more on the construction of the PSC.

In 1902, the Japanese government knew that the Commercial Pacific Cable Company (CPCC) was going to lay the submarine cable between San Francisco and Manila via Hawaii and Guam-which project was completed in 1903. The Japanese government therefore, began its negotiations with the CPCC, regarding the laying of a submarine cable between Guam and Japan, though the former was very much aware that the US government might not approve the landing to Guam [20]. However, the government decided to go ahead with the plan and then negotiate with the US government later, as its war with Russia became unavoidable.

The US government, however, did not easily approve the landing to Guam because of the neutrality stance of the US in such a war. Instead, a compromise was reached which allowed the Japanese government to lay a submarine cable between Yokohama and the Bonin Islands, both of which were Japanese territories, and for the CPCC to connect the Bonin Islands and Guam. In 1905, an official contract was signed by the Japanese government and the CPCC [21]. Finally, in 1906, a submarine cable was laid between Tokyo and Guam thus directly connecting Japan and the US.

The Japanese government finally believed that it had been able to break free from its dependency on the GNTC after the PSC construction was completed. However, it turned out that the GNTC owned CPCC's capital thus making it equally active in the laying of the PSC [22]. In the end, it became obvious that Japan could not completely escape from the GNTC's control as it had anticipated, regarding its ability to formulate its own independent submarine cable communications policy, despite the many benefits it had gained from the new technology. Furthermore, there was no improvement in the distribution of international news due to the exclusive treaties that existed among 
the UK, France and the US [23].

\section{Conclusions}

The submarine cable served as an important technological weapon for empire-building, especially for western countries including the UK and the US, in the latter part of the 19th and early 20th centuries, due to its economic and military advantages. Although Japan which had just begun its modernization process, was eager to acquire the new technology for its domestic and international growth, still it had to depend upon foreign companies to lay the international submarine cable due to its lack of funds and technological expertise.

To counter this dependency, Japan considered the construction of the Pacific Submarine Cable as critical in its attempts at escaping from the monopolistic control over the technology by the GNTC in the country. However, the momentum for the construction of the PSC intensified in Japan, following the end of the Sino-Japanese War (1894), especially due to Japan's expanding economy and international trade. The promotion of the PSC plan to assist with domestic and international trade was led by government officials and the business community. The PSC plan, therefore, added the economic dimension to Japan's international submarine cable policy. Additionally, the escalating conflict between Japan and Russia made the Japanese government realize the military importance of the PSC.

In 1906, the PSC was finally constructed by the CPCC connecting the North American continent and Japan taking almost forty years to materialize. Despite the many beneficial outcomes that resulted from the completion of the PSC to the country, the Japanese government was never able to achieve its goal of breaking free from the monopolistic control of the GNTC, regarding its desire to formulate its own independent submarine cable policy. However, the completion of the PSC contributed to the expansion and growth of the Japanese domestic economy and international trade, and the country as a whole.

Previous studies conducted, in regard to the Japanese international submarine cable policy, tended to focus on Japan's relationship with the GNTC and analyzed from the perspective of empire-building. This article, however, has argued the importance of the PSC and depicted its laying process from the economic aspect revealing that the business community and some political figures contributed to the completion of the PSC by appealing for its economic significance within Japan.

\section{References}

[1] Yang, D.Q. (2010) Technology of Empire: Telecommunications and Japanese Expansion in Asia, 1883-1945. Harvard University Asia Center, Cambridge, 8.

[2] Ariyama, T. (2013) Jōhō Haken to Teikoku Nihon (Information Hegemony and Japan). Vol. 1, Yoshikawa Kōbunkan, Tokyo, 246.

[3] Nakamura, T. (1985) Meiji Taishōki no Keizai (Japanese Economy in Meiji and Taisho Era). University of Tokyo Press, Tokyo, 85. 
[4] Sakatani, Y. Tokyo Keizaigaku Kyōkai no Setsuritunitsuite (About Establishing Tokyo Economic Association). Sakatani Yoshirō Kankei Monjo (Documents about Yoshirō Sakatani). Reel No. 45, Kensei Shiryō Shitsu, Kokuritsu Kokkai Toshokan.

[5] (1897) Taiheiyō Kaitei Denshinsen Fusetsu Chōsa Hōkoku (Investigating Report for Laying the Pacific Submarine Cable). Tokyo Keizai Zasshi.

[6] Nichibei Kaiteidensen Chinsetsu no Kyūmu (The Urgent Necessity of Laying a Submarine Cable between Japan and the US). Taiheiyōsen Keikaku (Teishin Sōgō Hakubutsukan, Japan).

[7] Summary of the Negotiation with British General Post Office about the Submarine Cable by Kenjirō Den, No Date. JACAR (Japan Center for Asian Historical Records National Archives of Japan) Ref. B04011012400 (7-15), Taiwan Hong Kong Kan Kaitei Densen Chinsetsu Ikken, (1-7-4) (Gaimushō Gaikō Shirōkan, Japan).

[8] (1897) From Yasushi Nomura, Minister for Communications, to Shigenobu Ōkuma, Minister for Foreign Affairs, 3-5.

[9] Ariyama, T. (2013) Jōhō Haken to Teikoku Nihon (Information Hegemony and Japan). Vol. 1, Yoshikawa Kōbunkan, Tokyo, 245-246.

[10] Shibusawa Seien Kinen Zaidan Ryūmonsha (1958) Shibusawa Eiichi Denki Shiryō (Biography of Shibusawa Eiichi). Vol. 23, Shibusawa Eiichi Denki Shiryō Kankōkai, Tokyo, 427.

[11] Yoshiyasu, E. (1997) Jūkyūseikimatsu Nihon no Kantaiheiyō Kōsō Kaneko Kentarōni okeru Ronri to Tenkai (Kaneko Kentarō's Logic and Evolvement for Pacific Rim Conception in the Late 19th Century). Historia, 158, 188.

[12] Yoshiyasu, E. (1997) Jūkyūseikimatsu Nihon no Kantaiheiyō Kōsō Kaneko Kentarōni okeru Ronri to Tenkai (Kaneko Kentarō’s Logic and Evolvement for Pacific Rim Conception in the Late 19th Century). Historia, 158, 198-204.

[13] Ōtani, K. (1928) Zuisho no Haruwo Mukaete (Auspiciousness Spring). Yasuke Yamukai, Yokohama, 12-15.

[14] Report of the International Commercial Congress, Seventh Day's Session, Philadelphia, Thursday, October 19, 1899. Seventh Day, October 19. Morning Session. JACAR Ref. B07080370200 (5-6), Bankoku Shōgyō Kaigi Ikken (B-2-9-5-0-16) (Gaimushō Gaikō Shirōkan, Japan).

[15] Ōtani, K. (1987) Ōbei Manyu Nisshi (Journal of Traveling in Europe and the US). In: Hideo Arai, Yumani Shobō, Tokyo, 166-167.

[16] (1899) For a Pacific Cable. The New York Times, 11th February, 4.

[17] (1899) The President's Annual Message. The New York Times, 6th December, 5.

[18] The Following Description Is Based on "Taiheiyō Kaitei Denshin Fusetsuni Kansuru Ketsugian (The Proposal for Laying the Pacific Cable). Proposed 26th January 1900, Shū (The Lower House), 67th, Kokuritsu Kokkai Toshokan, Japan.

[19] Proposal for Telegraphic Communication between Japan and the United States by Masatake Terauchi, Deputy Director of Army Chief of Staff, 21st December 1901. JACAR Ref. C03022793500 (6-8) Rikugunshō Hisoka Dainikki Meiji 36 Nen (Bōeishō Bōei Kenkyūjo).

[20] Ariyama, T. (2013) Jōhō Haken to Teikoku Nihon (Information Hegemony and Japan). Vol. 1, Yoshikawa Kōbunkan, Tokyo, 251-253.

[21] Ariyama, T. (2013) Jōhō Haken to Teikoku Nihon (Information Hegemony and Japan). Vol. 1, Yoshikawa Kōbunkan, Tokyo, 256-257.

[22] Ahvenainen, J. (1981) The Far Eastern Telegraphs: The History of Telegraphic Communications between the Far East, Europe, and America before the First World War. Suomalai- 
nen Tiedeakatemia, Helsinki, 174.

[23] Ariyama, T. (2013) Jōhō Haken to Teikoku Nihon (Information Hegemony and Japan). Vol. 1, Yoshikawa Kōbunkan, Tokyo, 249.

Submit or recommend next manuscript to OALib Journal and we will provide best service for you:

- Publication frequency: Monthly

- 9 subject areas of science, technology and medicine

- Fair and rigorous peer-review system

- Fast publication process

- Article promotion in various social networking sites (LinkedIn, Facebook, Twitter, etc.)

- Maximum dissemination of your research work

Submit Your Paper Online: Click Here to Submit

Contact Us: service@oalib.com 